\title{
TRENDS IN AND PERCEPTIONS ON URBANISATION
}

\author{
GeEtha RedDy ANANT \\ Centre for Indian Ocean Studies, Osmania University, Hyderabad, India
}

Manuscript received August 5, 2011

Revised version September 13, 2011

\begin{abstract}
Reddy Anant G., Trends in and perceptions on urbanisation. Quaestiones Geographicae 30(4), Bogucki Wydawnictwo Naukowe, Poznań 2011, pp. 21-31, 7 figs, 3 tables. DOI 10.2478/v10117-011-0034-9, ISBN 978-83-62662-88-3, ISSN 0137-477X.

AвSTRACT. Escalating mega-city concentrations, perpetuated by investment distortions and rural-urban imbalances in densely populated and economically undeveloped countries, endorse migration, generate pluralities, and create potential conditions for conflict, evoking planners' concern. In a globalising world, national policies tend to comply with international agreements, which do not necessarily synchronise with commitment of welfare states to domestic issues arising from inequities. This is more apparent in economies disadvantaged by large population sizes, sprawling urban agglomerations, preponderance of slums, a large proportion of untrained and illiterate human resources, and differential taxation laws. This paper appraises selected Indian Ocean countries characterised by development imbalances, lop-sided and unmanageable urbanisation on account of limited availability and poor allocation of resources, shift of rural poverty to urban areas, consumption inequities, etc. Most governments have embraced largely aggressive approaches to address this problem, evicting the 'destitute inmigrants', or forcibly shifting them. These cannot have a positive and far-reaching impact, and hence incentivebased 'inclusive' and 'participatory' resettlement strategies are urged.
\end{abstract}

KEY WORDS: agglomeration, FDI, plurality, anonymity, policy responses

Geetha Reddy Anant, Director, Centre for Indian Ocean Studies, Osmania University, Hyderabad 500 007, Andhra Pradesh, India; e-mail: geeta_a_reddy@rediffmail.com

\section{Introduction}

Uncontained population increases and their unequal spatial distribution have been a source of concern the world over, though the direction and degree of concern varies. The sources of concern include rural-urban, urban-rural, urban-urban, non-metropolitan-to-urban agglomerations and international migrations. Since 1976 the approach to address this, based on the trends, has fluctuated from a non-interventionist stand to efforts to encourage, prevent or even minimise population movement and concentration trends in each country by the respective governments.
This is justified and determined by the problems that arise, distribution trends experienced, and the competence and capability of each country and respective urban government to address them.

The scope of this paper is to survey trends in urbanisation, appraise the research orientations, and examine policy options designed and implemented in the light of human concerns and the UN Millennium Development Goals. For this purpose some countries of the Indian Ocean region have been selected as cases for examination, with the help of data extracted from UN reports, statistics, and secondary sources such as project 
reports and research publications, including web sites.

\section{Urban concentration}

The population distribution the world over is increasingly oriented toward urban settlements. A UN 2007 report estimated that by 2008 over half of the world's population would reside in urban areas for the first time in human history (United Nations 2007). Though both the developed and developing countries experience the existence and growth of large cities, the magnitude of the problem is likely to be greater in the latter case and the implications will be felt globally, it is feared. African and Asian countries are expected to experience it more acutely.

Predominating in the Indian Ocean countries are the populations of India and Indonesia with persistently the highest concentrations, as substantiated in Table 1 and Fig. 1. Natural growth, supported by progressive improvement in food supplies, their affordability, and expanding healthcare reducing mortality rates, is primarily responsible for this. It is those factors together that impact the level of urbanisation, which is only important when examined against the total geographical area of a country, its resource base, and the total population it supports. The implication of this statement is illustrated in Figs 1 and 2. For instance, if Australia, Singapore, Saudi Arabia, Iran and Mauritius have exceptionally high proportions of urban populations, they also have the necessary financial and technological wherewithal to sustain them. Further, the total population base is small and hence the numbers residing in the primate cities would correspondingly be small and manageable. Conversely, India, Pakistan, Indonesia and Bangladesh have relatively lower shares of urban populations. But their population bases are gigantic, their financial and resource bases weak, and management mechanisms not advanced enough. Hence the attendant

Table 1. Selected Indian Ocean countries: population and level of urbanisation $(1975,2004,2015)$

\begin{tabular}{|c|c|c|c|c|c|c|c|}
\hline \multirow{2}{*}{$\begin{array}{l}\text { Develop- } \\
\text { ment level }\end{array}$} & \multirow{2}{*}{ Country } & \multicolumn{3}{|c|}{ Population (m)* } & \multicolumn{3}{|c|}{ Level of urbanisation $(\%)^{*}$} \\
\hline & & 1975 & 2004 & 2015 & 1975 & 2004 & 2015 \\
\hline $\mathrm{H}$ & Australia & 13.6 & 19.9 & 22.2 & 86 & 88 & 90 \\
\hline $\mathrm{H}$ & Singapore & 2.3 & 4.3 & 4.8 & 100 & 100 & 100 \\
\hline $\mathrm{H}$ & Malaysia & 12.0 & 24.9 & 29.6 & 38 & 66 & 75 \\
\hline $\mathrm{H}$ & Mauritius & 0.9 & 1.2 & 1.3 & 43 & 42 & 44 \\
\hline $\mathrm{M}$ & Thailand & 41.0 & 64.0 & 69.0 & 24 & 32 & 36 \\
\hline M & Saudi Arabia & 7.3 & 24.0 & 30.8 & 58 & 81 & 83 \\
\hline $\mathrm{M}$ & Sri Lanka & 14.0 & 20.6 & 22.3 & 20 & 15 & 16 \\
\hline $\mathrm{M}$ & Iran & 33.3 & 69.0 & 80.0 & 46 & 66 & 72 \\
\hline $\mathrm{M}$ & Indonesia & 134.0 & 220.0 & 247.0 & 19 & 47 & 59 \\
\hline $\mathrm{M}$ & Egypt & 39.0 & 73.0 & 88.0 & 44 & 43 & 45 \\
\hline $\mathrm{M}$ & South Africa & 29.0 & 47.0 & 48.0 & 48 & 59 & 64 \\
\hline $\mathrm{M}$ & India & 621.0 & 1087.0 & 1260.0 & 21 & 29 & 32 \\
\hline $\mathrm{M}$ & Myanmar & 30.0 & 50.0 & 55.0 & 24 & 30 & 37 \\
\hline $\mathrm{M}$ & Pakistan & 68.0 & 155.0 & 193.0 & 26 & 35 & 40 \\
\hline $\mathrm{M}$ & Bangladesh & 73.0 & 139.0 & 168.0 & 10 & 24 & 30 \\
\hline $\mathrm{M}$ & Nepal & 13.5 & 27.0 & 33.0 & 4 & 15 & 30 \\
\hline $\mathrm{M}$ & Sudan & 17.0 & 36.0 & 44.0 & 19 & 40 & 50 \\
\hline $\mathrm{M}$ & Uganda & 11.0 & 28.0 & 42.0 & 7 & 13 & 15 \\
\hline $\mathrm{L}$ & Zimbabwe & 6.0 & 13.0 & 14.0 & 20 & 35 & 41 \\
\hline $\mathrm{L}$ & Kenya & 14.0 & 34.0 & 44.0 & 13 & 21 & 24 \\
\hline $\mathrm{L}$ & Tanzania & 16.0 & 38.0 & 46.0 & 11 & 24 & 29 \\
\hline $\mathrm{L}$ & Zambia & 5.0 & 12.0 & 14.0 & 35 & 35 & 37 \\
\hline $\mathrm{L}$ & Ethiopia & 34.0 & 76.0 & 97.0 & 10 & 16 & 19 \\
\hline
\end{tabular}

* Note : All figures have been rounded off.

Source: extracted from Table 5, Prospective Population Figures, pp. 297-300, UN, New York, 2006. 


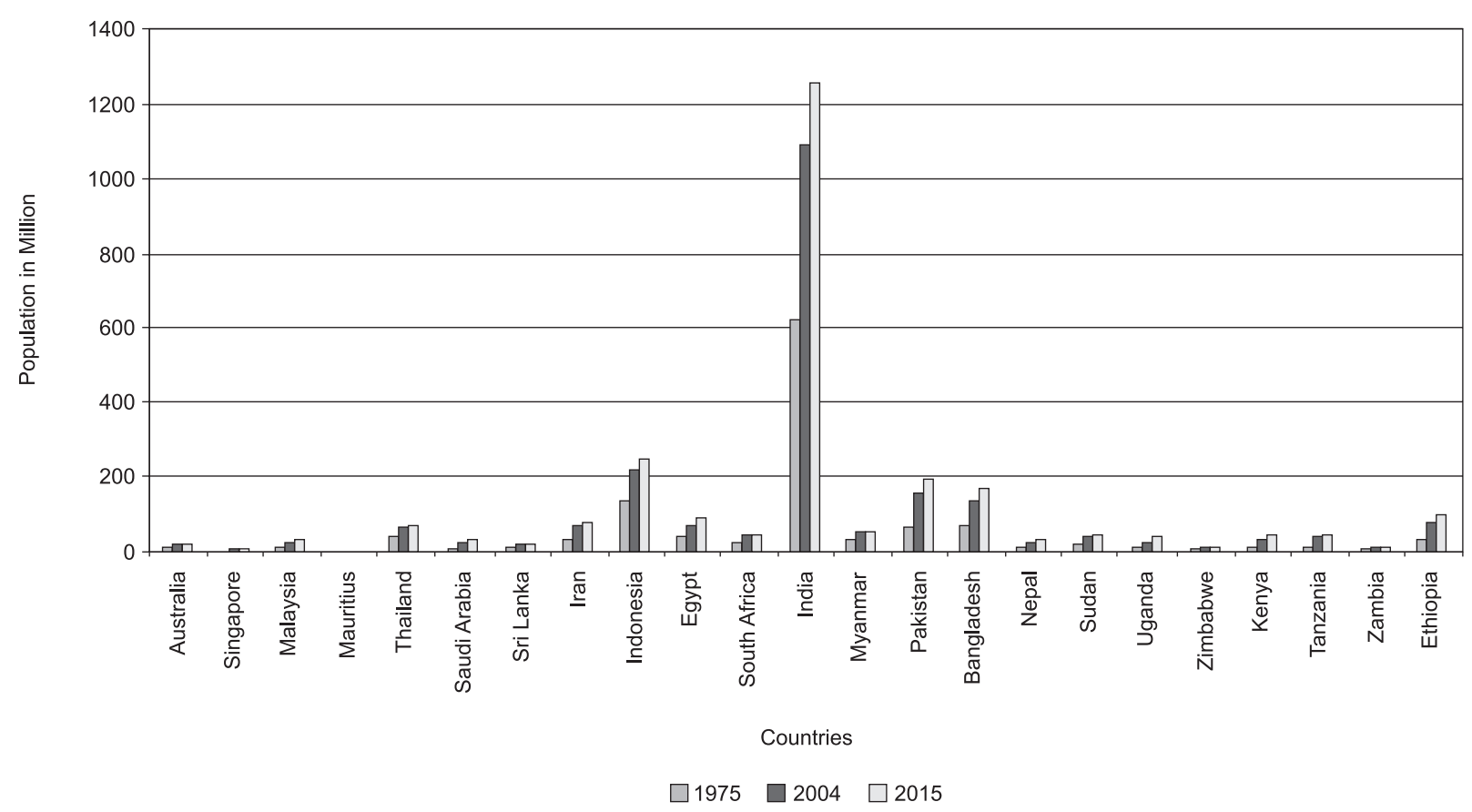

Fig. 1. Selected Indian Ocean countries: population (m) in 1975, 2004 and 2015.

Source: computed on the basis of data from World Urbanisation Prospects 2001 and World Population Policies 2005, UN.

problems are too numerous and complex, justifying the anxiety.

Urbanisation is not a recent phenomenon in most Indian Ocean countries (India, Iraq, Iran, Pakistan, Zimbabwe, etc.), but its volume and size certainly are, and show wide variations across the countries. The presence of primate cit- ies and urban agglomerations of massive, even intimidating sizes, means that the concentration of populations in very large settlements is going to continue (Reddy Anant 1994). Some very historical urban settlements have survived the tests of time and competition - either in a changed form in tune with altering market demands or

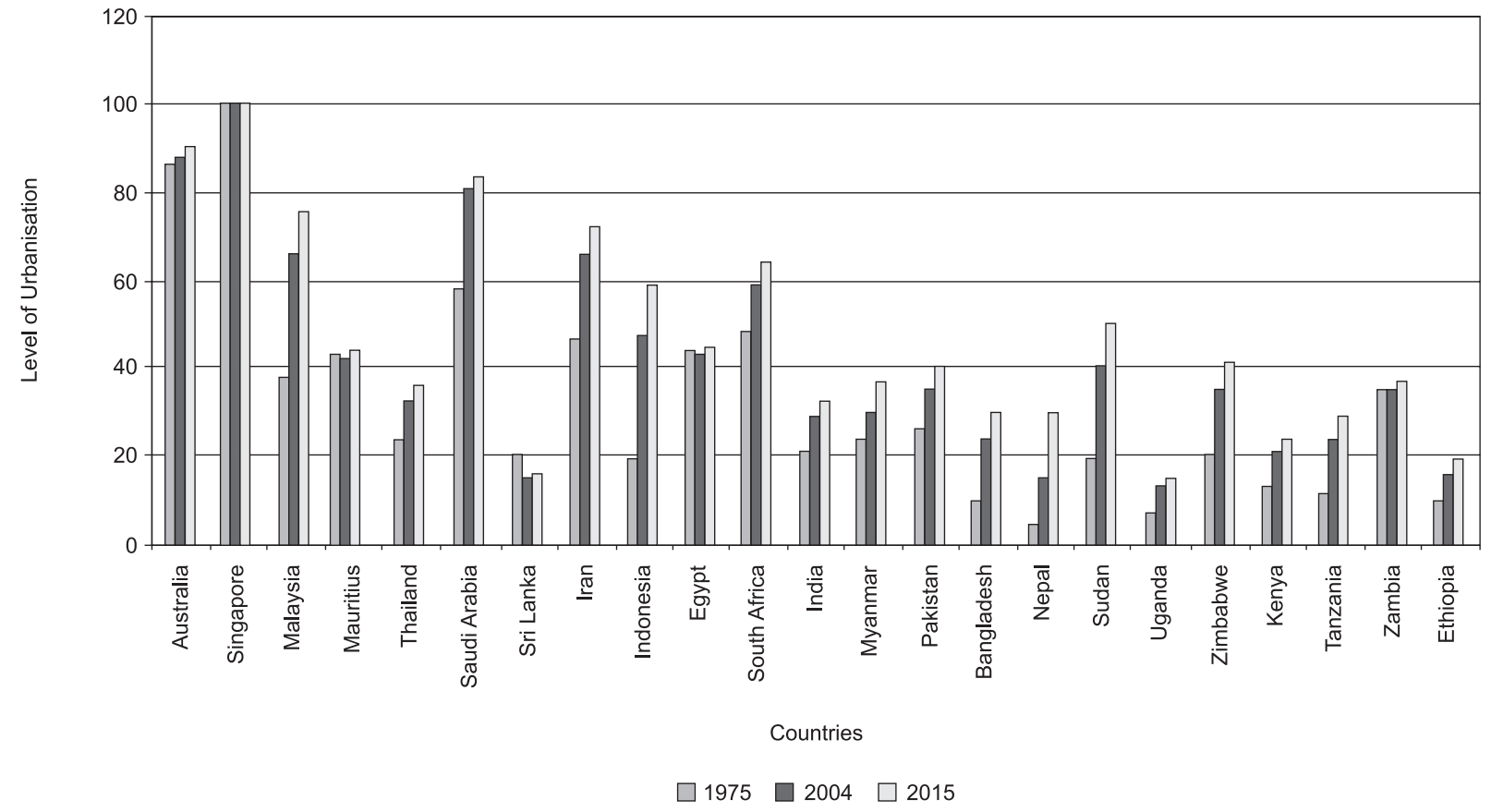

Fig. 2. Selected Indian Ocean countries: urbanisation level in 1975, 2004 and 2015.

Source: computed on the basis of data from World Urbanisation Prospects 2001 and World Population Policies 2005, UN. 
Table 2. Urban concentration in major cities of selected Indian Ocean countries

\begin{tabular}{|c|c|c|c|c|c|c|c|}
\hline \multirow{2}{*}{ City } & \multicolumn{3}{|c|}{$\%$ Urban population in major cities } & \multirow{2}{*}{$\begin{array}{c}\text { Rank in } \\
2000\end{array}$} & \multicolumn{3}{|c|}{$\%$ Urban population in major cities } \\
\hline & 1990 & 1995 & 2000 & & 2005 & 2010 & 2015 \\
\hline Johannesburg & 11.7 & 11.7 & 12.0 & 14 & 12.4 & 12.7 & 12.7 \\
\hline Harare & 36.0 & 38.7 & 40.2 & 2 & 40.8 & 40.7 & 40.1 \\
\hline Lusaka & 30.7 & 36.5 & 40.0 & 3 & 41.9 & 41.8 & 40.9 \\
\hline Dar es Salaam & 23.2 & 19.9 & 18.7 & 10 & 18.3 & 18.2 & 17.9 \\
\hline Kampala & 39.2 & 37.9 & 36.8 & 4 & 35.6 & 34.5 & 33.8 \\
\hline Blawayo & 19.6 & 19.2 & 18.5 & 11 & 18.0 & 17.7 & 17.5 \\
\hline Nairobi & 24.4 & 22.6 & 21.8 & 8 & 21.9 & 22.1 & 22.1 \\
\hline Sana & 25.6 & 27.5 & 29.3 & 6 & 30.0 & 29.9 & 29.3 \\
\hline Baghdad & 33.6 & 32.2 & 31.4 & 5 & 30.2 & 29.2 & 28.4 \\
\hline Tehran & 19.3 & 17.2 & 15.5 & 12 & 14.3 & 13.4 & 12.8 \\
\hline Karachi & 21.3 & 21.5 & 21.5 & 9 & 21.2 & 20.7 & 20.1 \\
\hline New Delhi & 3.8 & 4.1 & 4.5 & 16 & 4.9 & 5.2 & 5.3 \\
\hline Bangkok & 57.6 & 58.3 & 59.2 & 1 & 58.8 & 57.6 & 55.9 \\
\hline Kuala Lumpur & 12.6 & 11.5 & 10.8 & 15 & 10.5 & 10.3 & 10.2 \\
\hline Jakarta & 13.7 & 13.0 & 12.7 & 13 & 12.6 & 12.7 & 12.6 \\
\hline Sydney & 24.5 & 23.3 & 22.5 & 7 & 22.1 & 21.9 & 21.5 \\
\hline
\end{tabular}

Source: extracted and compiled from World Urbanisation Prospects 2001, UN.

maintaining a status quo, thus demonstrating great resilience. However, as Table 2 indicates, there have been increases in the proportion of the urban population since 2000 and the trends are likely to continue over the succeeding years (Schlein et al. 2007). A doubling of the urban population in the countries of Africa and Asia by 2030 is forecast by the study cited. This, it is explained, will not be largely due to natural increase, but through migration. The present rates are very high and portray diverse problems of unmanageable magnitude. Zambia, Mauritius, Thailand and Australia as exceptions have experienced only marginal increases, while Sri Lanka and Egypt display declines. In the rest of the Indian Ocean region countries, the urban base has expanded and, despite policies discouraging migration to urban settlements, the trends projected show increases. Of particular significance are the marked differences between metropolitan and non-metropolitan urban settlements and the emergence and persistence of urban primacy both at regional and national levels.

The share of the urban population in primate cities continues to be the highest in Bangkok, whose primacy of over 60 percent during 19701990 (Reddy Anant 1984) appears to persist (Fig. 3). What is apparent is that though the shares have increased in most metropolitan cities, they are ex- pected to decline in the period 2015-2050. New Delhi, however, is an exception, being the only city whose share is expected to increase. These concentrations in the largest cities adequately illustrate the continued focus of investment in primate cities and absence of alternatives, coupled with neglect of the rural region and economy.

The incidence of urbanisation itself is not the problem. It is the polarisation and unmanageable densities and agglomerations in some of the largest cities that are sources of concern to countries as well as international institutions like the World Bank and the UN, which have persistently highlighted the problems emergent upon lop-sided and unmanageable urbanisation patterns in developing countries (United Nations 2006). The reasons principally are the huge gaps between resource availability, allocative disabilities, and consequent multiplication of problems (environmental in particular) leading to poverty, overconsumption, absence of thrift and resource management, output maximisation, etc., leading in turn to global climate change and its rising repercussions (Aslin et al. 2004).

Various studies have ascribed this feature to two factors, viz. rural unemployment and poverty (as push factors), dichotomised by urban opportunities and infrastructural attractions (as magnetic forces). The poverty observable in ur- 


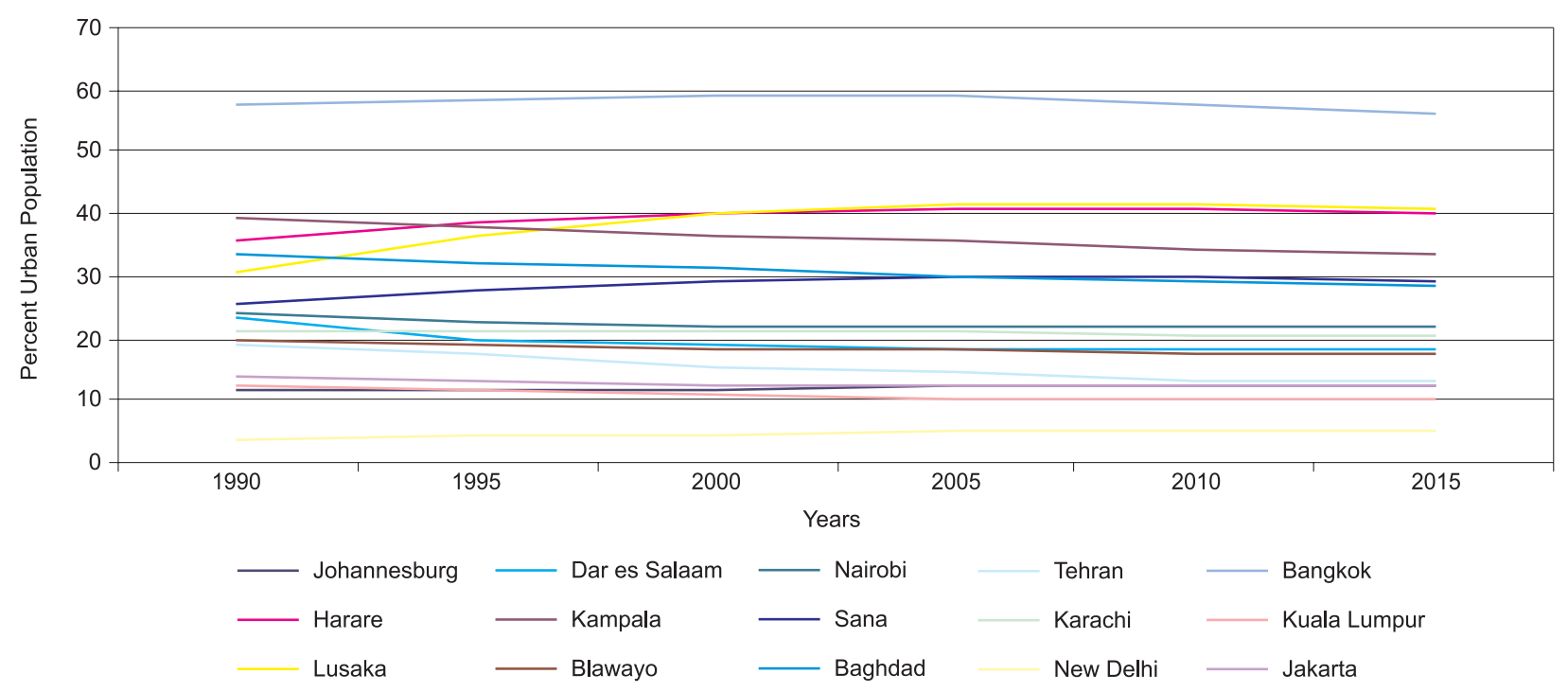

Fig. 3. Indian Ocean region: urban population concentration in the largest cities (1990-2015). Source: computed on the basis of data from World Urbanisation Prospects 2001 and World Population Policies 2005, UN.

ban settlements, particularly large metro-cities, is merely a transfer of rural poverty to urban enclaves - adding to the sprawl, litter, and general urban degradation.

\section{Intra-national competition}

The relative growth rates of the largest settlements in a country are fair indications of the direction of urban movements (reflecting the existing opportunities) and growth. The absence of an economically strong competitive second city, which happens when the first continues to be endowed with a larger share of inputs and investments, and when the second and subsequent cities are denied similar growth impulses, generally sustains the first city's primacy. In the event of such a trend, the first city continues to sprawl, as exemplified by many countries of the Indian Ocean region.

In South Africa, the growth of the five largest settlements, Johannesburg, Cape Town, Durban,

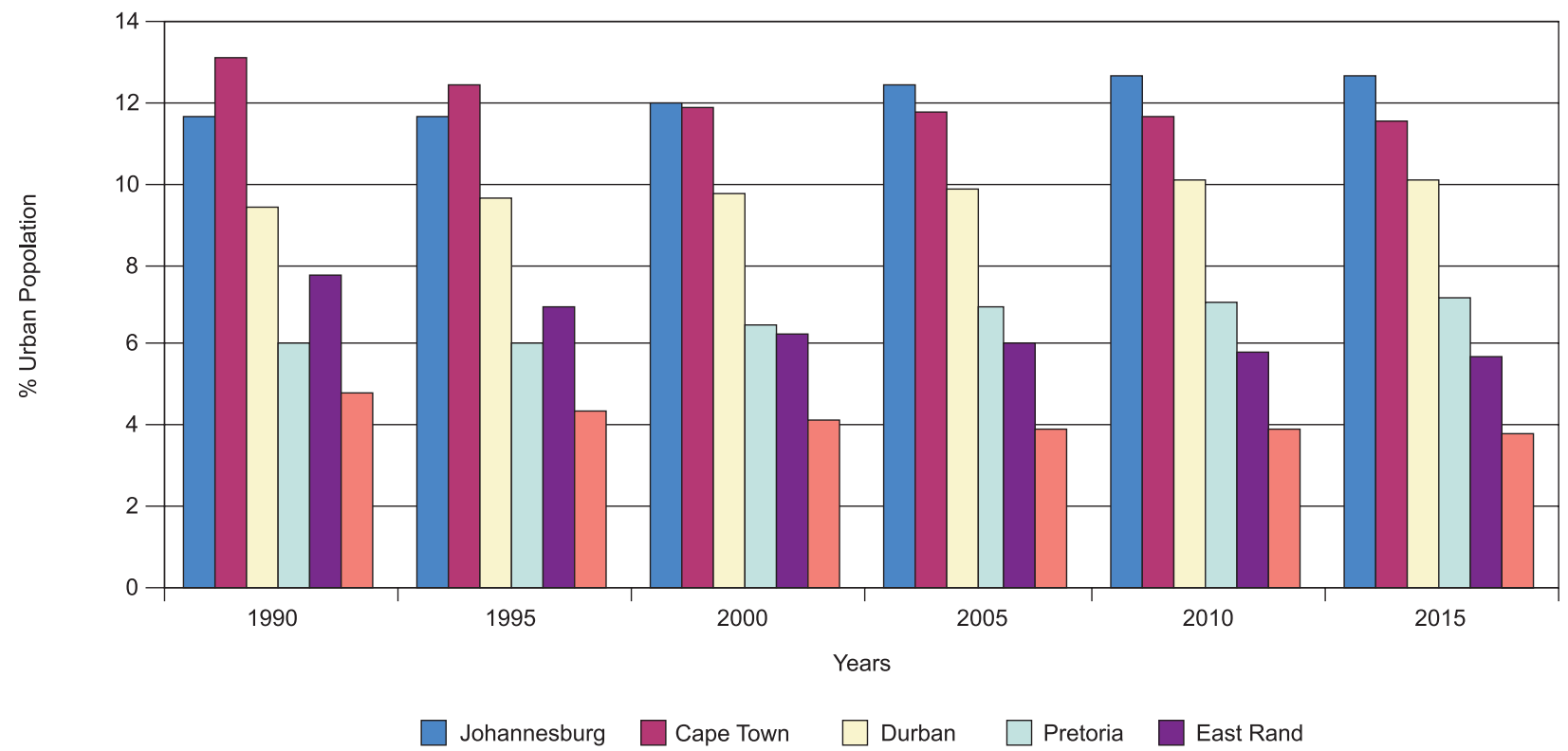

Fig. 4. South Africa: percent of the urban population in the largest cities.

Source: computed on the basis of data from World Urbanisation Prospects 2001 and World Population Policies 2005, UN. 


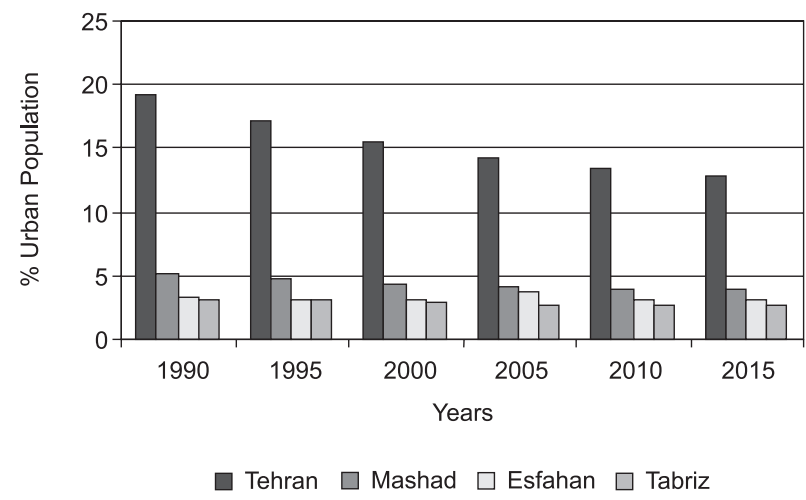

Fig. 5. Iran: percent of the urban population in the largest cities.

Source: computed on the basis of data from World Urbanisation Prospects 2001 and World Population Policies 2005, UN.

Pretoria, and East Rand, displays variations (Fig. 4). The competition between Johannesburg and Cape Town has enabled the former to out-do the latter. The growth of Johannesburg, Durban and Pretoria is expected to become sustained. But the growth of Cape Town and East Rand is expected to decline on account of their policies of urbanisation. Market forces even in a democratic set-up are not altogether independent of political overtures and tones of bias. Of particular interest is Durban. It is reported that its suburbs are fast expanding, pushing its peri-urban boundaries into the contiguous rural hinterland. However, the residents of this region are not being displaced or pushed out, as in the case of metro-cities in East and Central African countries. The post-apartheid policies, being more inclusive and laced with affirmative action, promote healthier growth and development, and the urban core and peripheries are no exceptions (Vidal 2007). South Africa, together with Kenya, exemplify rational planning and contrast sharply with Uganda and Tanzania (Barasa 2007).

In countries with a longer history of urbanisation and an economy supporting numerous large cities too, the largest tends to prevail - dominating the others. This is evident in Iran. Esfahan, Tabriz and Mashad are as old as Tehran, but the last continues to enjoy a primate position, even if diminishing (Fig. 5). A decline in the share of the other three has also simultaneously occurred. These facts are indicative of a more balanced spread of the population due to certain policy interventions, despite the numerous political changes that the country has witnessed.

In the case of India, its subcontinental size and very long history supports one of the largest numbers of urban settlements and the existence of at least four regional primates (Alam \& Reddy Anant 1987). Kolkata and New Delhi enjoy competitive growth rates, with the supremacy of the former expected to continue declining and the latter increasing, given the relative growth impulses of urban settlements in the adjacent states.

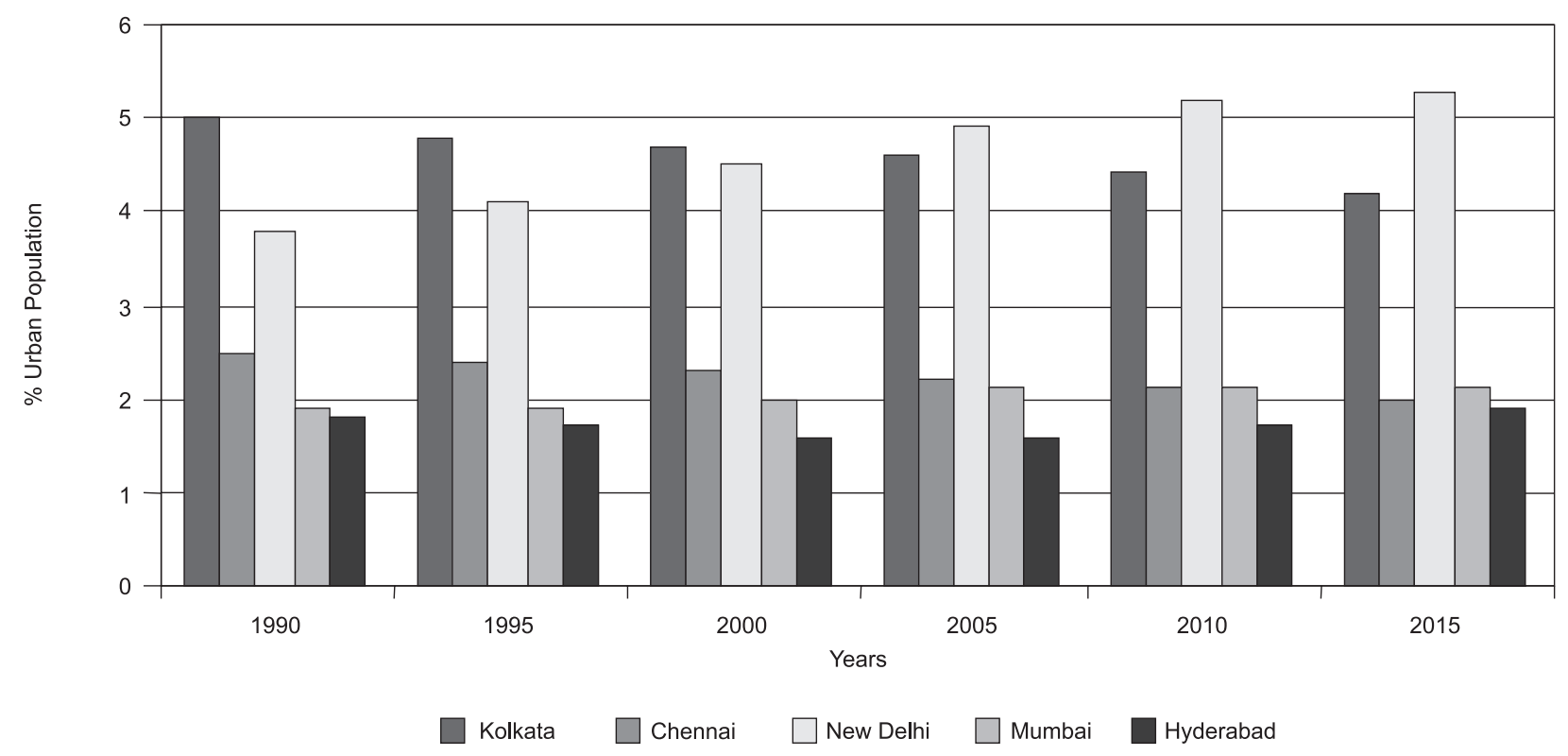

Fig. 6. India: percent of the urban population in the largest cities. Source: computed on the basis of data from World Urbanisation Prospects 2001 and World Population Policies 2005, UN. 


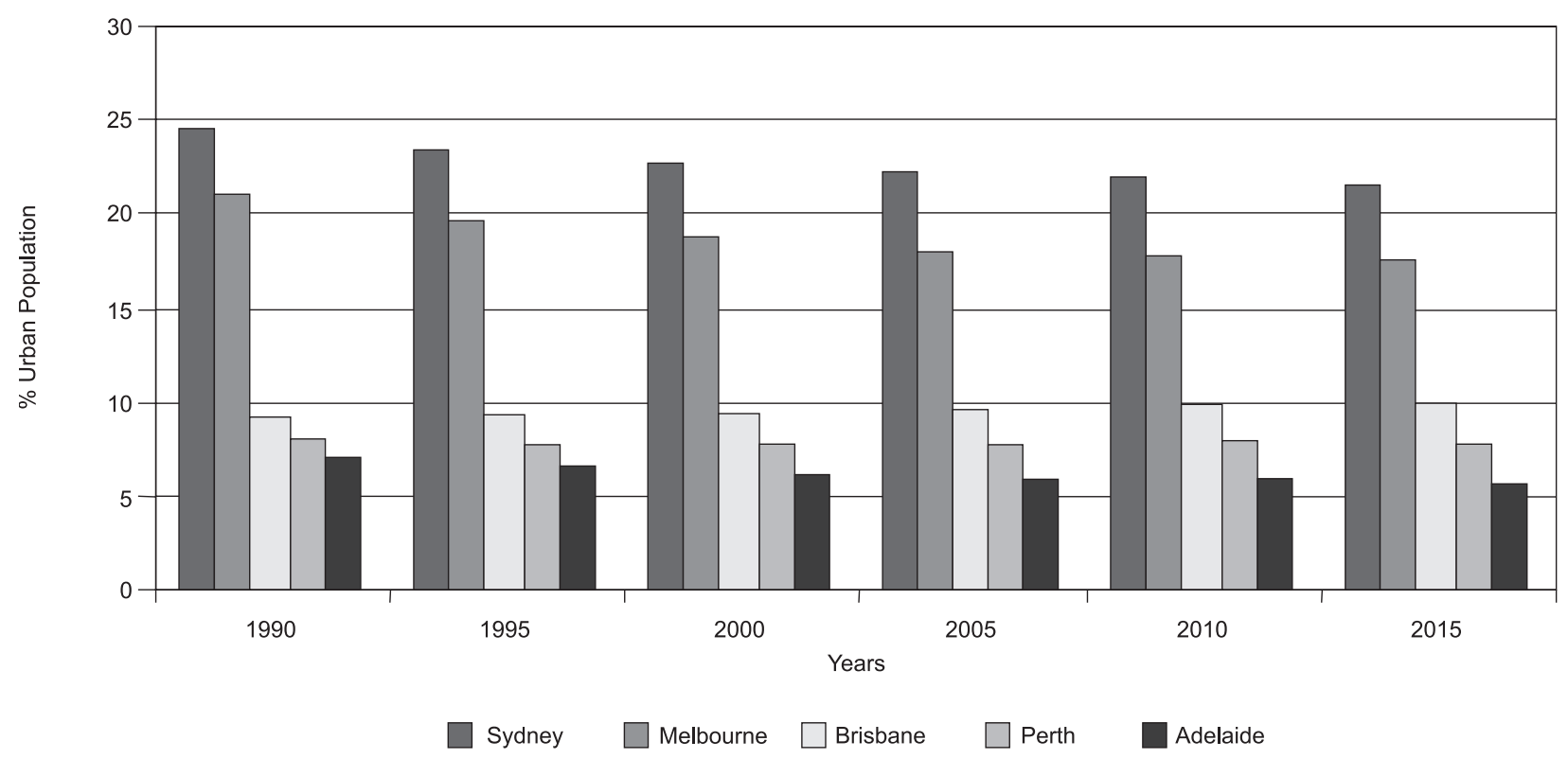

Fig. 7. Australia: percent of the urban population in the largest cities. Source: computed on the basis of data from 'World Urbanisation Prospects' 2001 and World Population Policies 2005, UN.

Chennai, Mumbai and Hyderabad show proximity, with Hyderabad displaying a tendency and possibility of outdoing the other two. The problem of inadequate resources confronting African countries also applies to India. The natural outcome is vast expansion - 'overspill', 'spill-over', 'sprawl', 'peri-urban growth', 'urban outgrowth', etc., each attracting research interest and modifying policies accordingly.

Australia, a country of continental dimensions, has two settlements - Sydney and Melbourne whose primate position and status remains unchallenged. But it is Brisbane that attracts more research in the field of peri-urban studies, driven by the changes visible there.

Maatthuis's study (2007) contending that generally the overall urban growth rate has declined in most parts of the world is partially correct. He maintains that cities grow because of the absolute size of the increments, through sheer momentum and snowball effects. The high densities in many of the world's largest cities compel more people to move out than in, e.g. Mumbai (with a population of 11.9 million in 2001), Sao Paulo (11.0 million in 2006), Shanghai (11.0 million in 2003), and Moscow (10.1 million in 2001). Among today's 20 mega-cities (10 million inhabitants or more), only six grew at rates consistently exceeding 3 percent a year over the last 30 years, he maintains. But if one examines trends in the rest of the largest cit- ies in the Indian Ocean countries, they continue to 'sprawl' and spill into peri-urban areas, whose boundaries are receding into the rural vicinity. Such expansions are a source of great concern and attract research into their implications for the character of peri-urban regions - for the residents-economy-environment on the one hand, and for the sustainability of the large cities they surround on the other.

\section{Research orientations}

The nature of the population distribution and changes in their profiles determine the kind of problems likely to occur and the policies required to meet the emerging challenges. Of late, urban studies have focused attention on environmental issues. A natural outcome of the differential natural resource endowment and development imbalances accentuated (as some believe) by the process of globalisation has been wage differentials and the resultant competition to seek employment in urban settlements, especially metropolitan settlements in general and in the service sector in particular. Compounding this trend is the fast expansion of metro-cities (mega-cities) and the concurrent expansion of urban peripheries, so that the receding peri-urban area (the area located between the truly 'urban' and 'ru- 
ral' regions) keeps displacing the erstwhile carefully tended farmland - the principal source of perishables for the metropolitan cities. This trend adversely affects food production and thus commodity pricing. The resultant shortage of food and price hike to unaffordable levels aggravates poverty conditions, enhancing malnutrition (Jinabhai et al. 1997) and undoing the decades of steady development achievements in improving the quality of life of citizens, especially marginal groups. These trends then underscore the importance of the objectives of the UN Millennium Development Goals.

Addressing urban poverty has not alleviated poverty in urban areas owing to the incessant influx from conditions of deprivation in rural areas and persistent conflicts in certain locales, justifying the need for new policies on migration. This includes the approach of municipal governments to the influx of the rural poor and the informal settlements which are considered eye sores and repugnant to foreign investors. There is a general consensus that urban population growth is too high, especially the rapid growth of urban agglomerations and emerging problems in the peri-urban regions (Dupont 2005), rural-to-urban migrations, and primate cities and large agglomerations of the developing countries. Their impact on food security and environmental hazards are equally major sources of concern for social sciences, health sciences, agricultural researchers, and planners. For instance, the growth rate of Chiengmai, the second largest settlement of Thailand, is breathtaking. The incursion of foreigners accentuates the pace of change and complexities, aggravating the environmental, managerial/ administrative, and security problems. It illustrates what is likely to occur in other Indian Ocean countries, especially those espousing new economic models. In many instances, the concentrations related with rural-urban population transfers/ shifts make it difficult for the new economic models to gain a hundred per cent success, for the following reasons:

1. the quality of the resident population presents a striking contrast with that of the migrant population coming from overseas;

2. the quality of the environment (infrastructure, etc.) designed to attract overseas populations and sustain modernisation is beyond afford- able limits of the 'poor' rural-urban migrants; and

3. people and finances from overseas are considered desirable because of the volume and technological character. In contrast is the rural-based population that moves in and the destitution characterising it which is found repulsive owing to the liability it is likely to be on the Exchequer. Their low purchasing power, poor capabilities (education and skills), inferior coping mechanisms (awareness levels) aggravate their undesirability once their utility as indispensable cheap labour force diminishes.

It is observed in many cases that the 'red car-

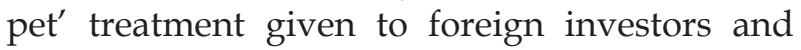
investments - through subsidies, incentives, concessions, special living and leisure spaces and investment zones, infrastructure, etc. - has evoked protests from local NGOs about the double standards: withdrawing subsidies and reducing support structures for small-time domestic players while extending them to larger players, and apprehensions about the possibility of the less educated, little or least qualified, semi- and unskilled local populations getting displaced by highly mechanical-oriented, well educated and highly skilled non-local workers, which could compound the problem of unemployment and insecurity. The 'locals' (indigenous) seek spaces in informality - seeking refuge and living in discarded spaces and derelict areas, prone to natural hazards and vulnerable to eviction policies and 'orders'. If one goes with the UN projection that by 203081 percent of the world's urban population is likely to live in African and Asian cities, and that an additional 1.7 billion urban dwellers will live there, they will pose increasing challenges to policy makers in Africa and Asia (Biriwasha 2007).

Funding from international/ supranational organisations, trans-national collaborative research, and an integrated approach to troubleshooting are the natural outcomes. "The way cities expand and organize themselves, both in developed and developing countries, will be critical for humanity" (Martine 1972) and "governance is the key issue" (Christopher Flavin, Worldwatch Institute president at a summer 2007 press conference). While the sprawling city (garden cities) and the 
compact city (smart growth) are two diverse approaches addressing urban patterns and structures considered distortions, they engender an equal number of problems to grapple with. Considering that metropolitan concentrations are inevitable consequences of an extensive incessant urban influx, preparedness with adequate infrastructure and amenities becomes mandatory, with complementary supportive funds.

\section{Policy opinions}

The problems accruing from the mal-distribution and overpopulation of the largest cities are multifarious. Since 1976, each government has adopted a different approach to rural-urban, urban-urban, urban-metropolitan, primate-cityoriented and urban-rural transfer of the population, either naturally, voluntarily, or through incentives or compulsion (Table 3), depending on its own capacity and requirements. All of them would like to discourage additions to existing urban agglomerations. But the strategies have varied with the situation. In Africa - Uganda, Kenya, Tanzania - more forceful and physical evictions have been taking place (Cheru 2005). In some cases warnings have been given of legal action in case the poor failed to shift from urban agglomerations to more removed places. Ogbu and Krugman (1999) ascribed the shifting of certain economic sections of the urban population to peri-urban sites to declining urban formal employment opportunities, high urban land prices, and high living costs in core areas. These trends are observed to precede strategies to access peri-urban land when the land in the core area reaches saturation. In the Indian context, in such situations peri-urban areas are observed to attract heavy investment by realtors and a sharp rise in land rates, which again tends to displace the newly settled lower-income groups and small farmers. The people who occupied the most economical and least desired of locations, with minimal or no infrastructure facilities and amenities like safe drinking water, shelter, health care facilities etc., are again compelled to shift to newer sites further away.

In many African countries governments adopted an unyielding stand in compelling them to shift. The principal reason, as mentioned earlier, was the fear of having to provide them with the basic amenities which most governments could not afford, and the apprehension of further degradation of the environment in urban agglomerations, which would deter prospective investors. Poverty, it should be conceded, is not a desirable factor, whether for the government, the affected groups, or the affluent class. But this should make policies adopt a more rigorous programmes of development with planned targeting of corrective strategies to selectively prioritised beneficiaries. However, the policies that each government adopts to address this influx are influenced by the process of globalisation, competition to attract FDI, and prevalent government disabilities (arising from limited resources). In South Asian countries, and others where democratic systems and structures are operational, the approach is 'with a human face'. In African countries, the approach is more aggressive, sometimes even termed 'brutal'. South Africa and Kenya are more democratic.

\section{Conclusion}

The overall urban scenario displays a growth decline the world over, with concentrations in one or a few settlements, especially in developing countries. The trend for these additions to converge in and around low-cost infrastructure-deficient suburbs and peri-urban zones is increasing in weak-economy countries compared with industrialised ones, whose experience of the late 1980s cannot constitute replicable lessons, given the spatio-temporal and politico-economic specificity of each case. The problems of these residents are real and have debilitating effects, but are not insurmountable. States with a feeble financial position have limited investment capabilities and hence cannot pursue aggressive extensive corrective development initiatives. It would then be difficult to expedite improvements in a comprehensive manner. Only some aspects of development can be addressed at a time. This tends to allow only slow and piecemeal progress, and thereby displeases the unaddressed regions, people and sectors. In such situations the response tends to be negative, as in some East and Central African 
Table 3. Selected Indian Ocean countries: government responses to population distribution

\begin{tabular}{|c|c|c|c|}
\hline Country & $<1980$ & 1980-2000 & $>2000$ \\
\hline $\begin{array}{c}\text { South Africa } \\
\text { urban population growth } \\
\text { rates relatively low at } 2.7 \% \text {; } \\
\text { expected decline to } 1.7 \% \\
\text { p.a. in } 2005-2030\end{array}$ & $\begin{array}{l}\text { Minor changes desired } \\
\text { in spatial distribution of } \\
\text { population }\end{array}$ & $\begin{array}{l}\text { Major changes desired in } \\
\text { population distribution; to } \\
\text { reduce rural-urban shifts }\end{array}$ & $\begin{array}{c}\text { To raise urban-rural trans- } \\
\text { fers \& maintain urban- } \\
\text { urban trends }\end{array}$ \\
\hline $\begin{array}{c}\text { Zimbabwe } \\
\text { urban population growth } \\
\text { rates have increased from } \\
6.0 \text { to } 6.5 \% \text { but tend to } \\
\text { decline; expected rates of } \\
4 \% \text { in } 2005-10 \text { and } 1.8 \% \text { in } \\
2010-2030\end{array}$ & $\begin{array}{l}\text { To reduce shifts to urban } \\
\text { agglomerations }\end{array}$ & $\begin{array}{c}\text { Concentrations in urban } \\
\text { agglomerations merited no } \\
\text { interference }\end{array}$ & $\begin{array}{c}\text { Now efforts to reduce } \\
\text { concentrations in urban ag- } \\
\text { glomerations }\end{array}$ \\
\hline $\begin{array}{l}\text { Zambia } \\
\text { urban population growth } \\
\text { rates have declined from } \\
6.5 \text { to } 3.2 \% \text {, but further } \\
\text { decrease desired }\end{array}$ & To lower rural-urban flows & $\begin{array}{l}\text { To raise urban-rural revers- } \\
\text { als; not to interfere with } \\
\text { urban-urban shifts }\end{array}$ & $\begin{array}{l}\text { Concentrations in urban ag- } \\
\text { glomerations to be reduced }\end{array}$ \\
\hline $\begin{array}{l}\text { Tanzania } \\
\text { sudden decline in growth } \\
\text { rates of urban population } \\
\text { from } 11.4 \text { to } 6.8 \% \text { and fur- } \\
\text { ther expected } 4.9 \% \text { p.a. }\end{array}$ & $\begin{array}{c}\text { Villagisation scheme con- } \\
\text { sidered ineffective, or even } \\
\text { a farce }\end{array}$ & To reduce urban levels & $\begin{array}{c}\text { Intervention to prevent } \\
\text { urban-to-metropolitan and } \\
\text { rural-to-metropolitan shifts }\end{array}$ \\
\hline $\begin{array}{l}\text { Kenya } \\
\text { high growth rates - } 8 \% \text { p.a.; } \\
\text { expected relative reduction } \\
\text { to } 6 \% \text { p.a. }\end{array}$ & $\begin{array}{l}\text { Major change desired; no } \\
\text { interference in rural-urban } \\
\text { flows }\end{array}$ & $\begin{array}{l}\text { Minor change desired; to } \\
\text { raise urban-rural flows; } \\
\text { no intervention in urban- } \\
\text { urban flows }\end{array}$ & $\begin{array}{l}\text { Major change desired; to } \\
\text { reduce urban agglomera- } \\
\text { tion increases }\end{array}$ \\
\hline $\begin{array}{l}\text { Pakistan } \\
\text { urban population growth } \\
\text { rates have declined since } \\
1985\end{array}$ & $\begin{array}{l}\text { Major changes desired in } \\
\text { spatial distribution }\end{array}$ & & $\begin{array}{l}\text { To encourage urban-rural } \\
\text { migration, maintain urban- } \\
\text { to-urban migration and } \\
\text { restrict urban-to-metro- } \\
\text { politan migration - even } \\
\text { lower it }\end{array}$ \\
\hline $\begin{array}{c}\text { India } \\
\text { urban population growth } \\
\text { rates at 3.8\% p.a. and ex- } \\
\text { pected to decline to } 2.7 \text { and } \\
2.3 \% \text { by } 2030\end{array}$ & Major change desired & $\begin{array}{c}\text { To lower rural-urban flows; } \\
\text { to increase urban-rural } \\
\text { ones }\end{array}$ & $\begin{array}{l}\text { To maintain urban-urban } \\
\text { flows, to reduce urban ag- } \\
\text { glomeration increase }\end{array}$ \\
\hline $\begin{array}{c}\text { Sri Lanka } \\
\text { urban population growth } \\
\text { rates are among the lowest } \\
\text { at } 2.0 \% \text { and anticipated to } \\
\text { drop further to } 1.0 \% \text { by } \\
2015 \text { and } 0.7 \% \text { by } 2030 \\
\end{array}$ & $\begin{array}{c}\text { To raise rural-urban shifts; } \\
\text { to maintain urban-urban } \\
\text { ones }\end{array}$ & $\begin{array}{l}\text { To raise concentrations in } \\
\text { urban agglomerations }\end{array}$ & $\begin{array}{l}\text { To lower concentrations in } \\
\text { urban agglomerations }\end{array}$ \\
\hline $\begin{array}{l}\text { Thailand } \\
\text { urban population growth } \\
\text { rates have been declining } \\
\text { and expected to drop to } \\
1.9 \% \text { p.a. }\end{array}$ & $\begin{array}{l}\text { To lower urban-to-rural } \\
\text { migrations }\end{array}$ & $\begin{array}{l}\text { Non-interference in urban- } \\
\text { to-rural movements }\end{array}$ & $\begin{array}{l}\text { To reduce urban-urban } \\
\text { migrations }\end{array}$ \\
\hline $\begin{array}{c}\text { Australia } \\
\text { urban population growth } \\
\text { rates are low at } 2.2 \% \text { and } \\
\text { further expected to drop to } \\
1.3 \text { or } 1.4 \% \text { by } 2030\end{array}$ & $\begin{array}{l}\text { Major interventions de- } \\
\text { sired; to lower rural-urban } \\
\text { flows }\end{array}$ & $\begin{array}{l}\text { Minor interventions de- } \\
\text { sired since } 1996\end{array}$ & $\begin{array}{l}\text { No interference in urban- } \\
\text { rural and urban-urban } \\
\text { shifts; to lower urban ag- } \\
\text { glomeration influxes }\end{array}$ \\
\hline
\end{tabular}

Source: World Population Policies 2005, pp. 346 and 351, 2006, UN, New York. 
countries where aggressive coercive methods are being used to vacate the 'destitute in-migrants', forcibly driving them to even greater destitution and impoverishment. The implication of the onward and backward flows and movements of such populations is shifting and shunting of poverty and the poor to places that reduce their visibility rather than resolving the problem effectively and with some degree of permanence. The present trends hence create a demand for more rigorous programmes of the much talkedabout 'inclusive' kind and 'participatory' in nature. A regional development approach, with incentives to move to the countryside and smaller urban settlements, can prove more fruitful with long-term remedial impacts. But the creation of at least relatively attractive conditions there is a pre-requisite, strengthened by at least modest occupational and income safeguards, laced with infrastructural adequacies, and cushioned with agriculture- and rural-industry-based subsidies.

\section{References}

Alam M.S. \& Reddy Anant G., 1987. Processes of urbanisation and the urban system of India. In: Alam M.S \& Alikhan F. (eds), Perspectives of urbanisation and migration: India and USSR. Allied Publishers, New Delhi: 19-80.

Aslin H., Kelson S., Smith J. \& Lesslie R., 2004. Peri-urban landholders $\mathcal{E}$ biosecurity issues - a scoping study. Australian Government, Bureau of Rural Sciences, Canberra.

Barasa L., 2007. Kenya: More citizens living in urban areas. The Nation, June 27, 2007.
Biriwasha M., 2007. Urban growth in Africa and Asia. A UNFPA report.

Cheru F., 2005. Globalization and uneven urbanization in Africa: The limits to effective urban governance in the provision of basic services. UCLA Globalization Research Center - Africa.

Dupont V., 2005. Peri-urban dynamics - population, habitat and environment on the peripheries of large Indian metropolises. CSH Occasional Paper, 14. French Research Institutes in India, Rajdhani Art Press, New Delhi.

Jinabhai C.C., Mametja D., Coovadia H.M. \& Gouws E., 1997. Development of a health programme in a peri-urban informal settlement in Besters, KwaZulu-Natal. South African Medical Journal, 87(6): 741-746.

Maathuis M., 2007. Cities to boom in Africa, Asia. UPI International Intelligence, July 3, 2007.

Martine G., 1972. Migration, natural increase and city growth: The case of Rio de Janeiro. International Migration Review, 6(2): 200-215.

Ogbu O. \& Krugman H., 1999. Ugandan environmental management of peri-urban settlement. Uganda National Council for Science and Technology, project report.

Reddy Anant G., 1984. Examining select primate cities of the Indian Ocean region. In: McPherson K. (ed.), The Indian Ocean Region - UNCLOS II. Curtin University, Australia.

Reddy Anant G., 1994. Urbanisation and primate city growth in the Indian Ocean countries. Sterling Publishers, New Delhi.

Schlein L., De Capua J. \& Kruger S., 2007. For humanity's sake - developing world must prepare for soaring urbanisation. UN Population Fund report, June 28, 2007.

United Nations Population Fund, 2006. State of world population 2006 - A passage to hope. UN, New York (www.unfpa. org/swp/2006/pdf/en_sowp06.pdf).

United Nations Population Fund, 2007. State of world population 2007 - Unleashing the potential of urban growth. UN, New York (www.unfpa.org/swp/2007/presskit/pdf/ sowp2007_eng.pdf).

Vidal J., 2007. Burgeoning cities face catastrophe, says UN. The Guardian, 28th June 2007. 